DOI: $10.2478 / \mathrm{v} .10169-010-0013-\mathrm{x}$

\title{
INFLUENCE OF FLY ASH FROM CO-COMBUSTION OF COAL AND BIOMASS ON SCALING RESISTANCE OF CONCRETE
}

\author{
M. KOSIOR-KAZBERUK ${ }^{1}$, D. JÓŹWIAK-NIEDŹWIEDZKA²
}

\begin{abstract}
Industrial utilization of fly ash from various kinds of fuel plays an important role in the environmentally clean and cost effective power production. The primary market for fly ash utilization is as a pozzolanic addition in concrete production. The paper concerns the concretes containing fly ash called Fly Ash from Biomass (FAB) from co-combustion of hard coal and wood biomass (wood chips). Characterization of the fly ash was carried on by means of X-ray diffractometry and E-SEM/EDS analysis. The results of laboratory studies undertaken to evaluate the influence of FAB on concrete resistance to surface scaling due to cyclic freezing and thawing in the presence of $\mathrm{NaCl}$ solution were presented. The tests were carried out for concretes containing up to $25 \%$ of fly ash related to cement mass. Additionally, the microstructure of air-voids was described.

It was concluded that the FAB has significant effect on concrete freeze/thaw durability. The replacement of cement by fly ash from co-combustion progressively transformed the concrete microstructure into less resistant against freeze/thaw cycles and excessive dosage (over 15\%) may dangerously increase the scaling.
\end{abstract}

Key words: concrete, durability, fly ash from co-combustion of coal and biomass, scaling resistance, microstructure.

\section{INTRODUCTION}

The co-combustion of coal and biomass is becoming more and more popular due to the EU regulations concerning the application of renewable sources of energy. The increased demand for energy is forcing towards more rational use of non-renewable sources of energy, together with the expansion of the renewable sources of energy, as well as the creation of ecologically and economically acceptable combination. Biomass has became an increasingly important energy source all over Europe, and the application of biomass in power plants makes a significant contribution to the reduction of $\mathrm{CO}_{2}$ emission. The combustion of wood biomass and coal in existing large-scale boilers offers several advantages over great boilers fired exclusively with biomass, such

\footnotetext{
${ }^{1}$ Białystok Technical University, Faculty of Civil Engineering and Environmental Engineering, Białystok, Poland, e-mail: m.kosior@pb.bialystok.pl

${ }^{2}$ Institute of Fundamental Technological Research, Polish Academy of Sciences, Warszawa, Poland, e-mail: djozwiak@ippt.gov.pl
} 
as high electrical efficiency and lower investment costs. Substituting biomass for coal also reduces $\mathrm{SO}_{2}$ emission through decreasing bound sulphur in fuel [1, 2].

Fly ash can be either an industrial waste material and ecological nuisance, or a valuable raw material. For the latter purposes, its properties need to be defined precisely and controlled so that a uniform and reproducible material can be supplied. Fly ash is widely utilized as an additive and its effects on the properties of Portland cement and concrete have been comprehensively investigated. However, there are many characteristic properties of fly ash coming from the co-combustion of a biomass fuel with a fossil fuel. Factors such as an origin of the coal and biomass, their proportions in fuel mix, as well as combustion conditions, strongly affect chemical and mineralogical composition(s) of fly ashes, resulting in the production of different kinds of fly ash [3, $4,15]$.

It is known that the incorporation of fly ash increases porosity of the hardened cement paste at early ages, but the average pore size is reduced, and this often results in a less permeable cement paste. The dense transition zone between aggregate and matrix is also a result of the use of fly ash. The concrete containing fly ash is, therefore, less susceptible to the ingress of harmful ions, [16].

In phenomenon of scaling resistance the ingress of aggressive ions can be reduced by fly ash as an additive or as a cement replacement. However, the FAB fly ash differs in physical and chemical properties from the traditionally used fly ashes. The useful properties of these materials have to be determined for every application.

The aim of the investigations was to determine the maximum amount of fly ash (FAB) from co-combustion of hard coal and wood biomass as a cement replacement that could be used without risk of scaling on external face of concrete structures. The frost resistance of concrete due to cyclic freezing and thawing with de-icing salt saturation was determined and tested according to PKN-CEN/TS 12390-9:2007, [5].

\section{EXPERIMENTAL PROGRAM AND DETAILS}

\subsection{Materials}

The ordinary Portland cement (OPC) CEM I 42,5 N-HSR/NA, river sand, fraction $0 \div 2 \mathrm{~mm}$, and the natural aggregate with maximum diameter of $8 \mathrm{~mm}$ were used. The ordinary concrete without any additive was made for reference, and the concretes with $5 \%, 15 \%$ and $25 \%$ cement replacement by fly ash from co-combustion of hard coal and wood biomass was prepared for testing. The fuel mixture burned in thermal power station consisted of $60 \%$ of coal and $40 \%$ of biomass from wood chips.

The chemical composition and specific gravity of (the) cement and fly ash from co-combustion of hard coal and wood biomass are presented in Table 1.

The phase composition of fly ash was determined on the basis of diffractional X-ray analysis, Fig. 1, [6]. The X-ray pattern of fly ash tested was different from X-ray 
Chemical composition of cement and fly ash from co-combustion of hard coal and wood biomass. Skład chemiczny cementu i popiołu lotnego pochodzącego ze współspalania węgla kamiennego i biomasy drzewnej

\begin{tabular}{|l|c|c|}
\hline Chemical composition & Cement & Fly ash \\
\hline $\mathrm{CaO}(\%)$ & 64.8 & 2.3 \\
\hline $\mathrm{SiO}_{2}(\%)$ & 21.2 & 51.6 \\
\hline $\mathrm{Al}_{2} \mathrm{O}_{3}(\%)$ & 4.10 & 22.8 \\
\hline $\mathrm{Fe}_{2} \mathrm{O}_{3}(\%)$ & 5.10 & 7.3 \\
\hline $\mathrm{MgO}(\%)$ & 0.8 & 1.3 \\
\hline $\mathrm{SO}_{3}(\%)$ & 2.0 & 2.2 \\
\hline $\mathrm{Na}_{2} \mathrm{O}_{e q}(\%)$ & 0.5 & 4.2 \\
\hline Loss on ignition $(\%)$ & 0.7 & 6.9 \\
\hline Specific gravity $\left(\mathrm{kg} / \mathrm{m}^{3}\right)$ & 3050 & 2240 \\
\hline
\end{tabular}

pattern of conventional fly ash from coal combustion. The tested material contained glassy and crystalline phases and amorphous glass, which was an active part of fly ash. Two main crystalline phases were determined: $\beta$-quartz and hematite. The fly ash contained also magnetite and iron sulfite. There was no mullite in fly ash tested. The lack of mullite, typical phase in conventional fly ash, can be explained by relatively low temperature of burning $\left(\right.$ c. $\left.850^{\circ} \mathrm{C}\right)$.



Fig. 1. X-ray pattern of fly ash used ( $\mathrm{Q}-\beta$-quartz, $\mathrm{H}$ - hematite, $\mathrm{C}-$ carbon, $\mathrm{F}$ - iron sulphate). Rys. 1. Wyniki dyfraktometrii rentgenowskiej popiołu lotnego wykorzystanego w badaniach ( $\mathrm{Q}$ - $\beta$-kwarc, $\mathrm{H}$ - hematyt, $\mathrm{C}$ - węgiel, $\mathrm{F}$ - siarczyn żelaza)

The shapes of fly ash grains were determined by using the environmental scanning electron microscope E-SEM Philips XL 30 operated with a poor vacuum in specimen 
chamber. The specimens did not need to be coated with a layer of electrically conductive material. The analysis of chemical composition of fly ash was carried out in selected points using the energy dispersive X-ray analyser EDS Link ISIS with acceleration voltage of $18 \mathrm{kV}$. The observations were conducted with magnification from 50 to 1000 times.

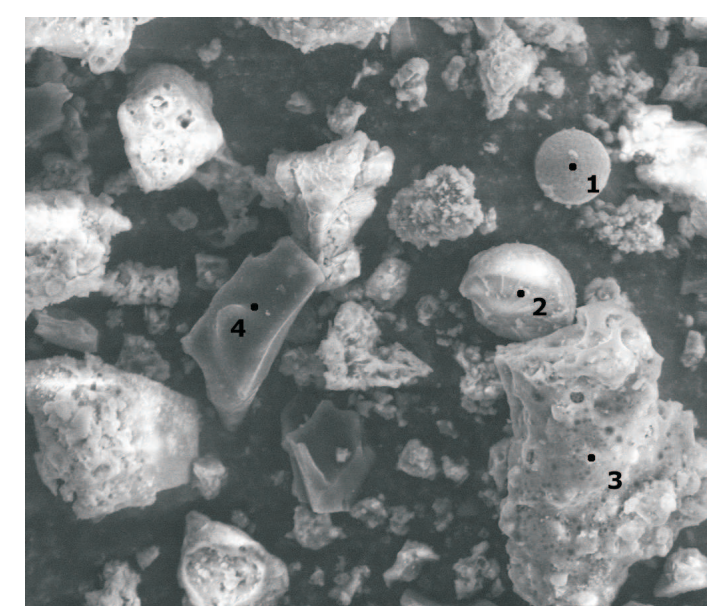

Fig. 2. E-SEM image of fly ash from co-combustion of hard coal and wood biomass, magnification $\times 5000$.

Rys. 2. Zdjęcie z mikroskopu skaningowego, popiół lotny ze współspalania węgla kamiennego i biomasy drzewnej, powiększenie $\times 5000$

The fly ash from co-combustion contains small number of spherical grains. The plate and elongated shapes were also found but the most of grains had irregular or shapeless form. In chemical composition such components as carbon (the specimens were not coated with carbon before investigation), which can cause pozzolanic activity decrease, phosphor and significant amount of calcium was observed. The conditions of combustion as well as the presence of biomass in fuel have an effect on composition of fly ash.

Pozzolanic activity of fly ash was evaluated according to standard EN 450-1 [7]. The pozzolanic activity index was determined on the basis of the comparison of compressive $\left(f_{c m}\right)$ of mortars containing $75 \%$ of cement and $25 \%$ of fly ash, and cement mortar without addition. The mortar mixture consisted of binder, water and fine aggregate in proportion 1:0.5:3. The value of pozzolanic activity index, determined after 28 and 90 days of curing, should exceed $75 \%$ and $85 \%$, respectively. The values of pozzolanic activity after 28 and 90 days were $96 \%$ and $100 \%$, respectively. The fly ash tested points out pozzolanic activity. 
a)

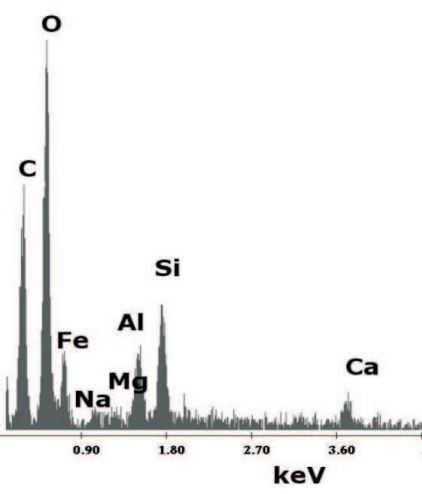

c)

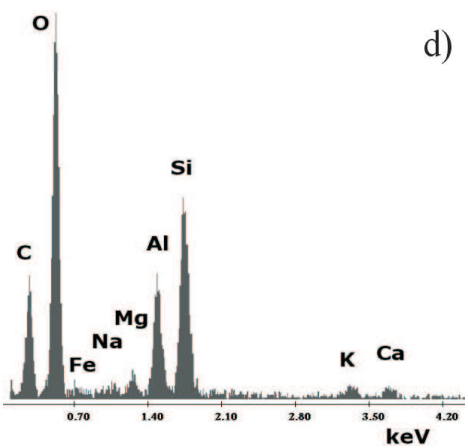

) b)


Fig. 3. EDS analysis results in points marked in Fig. 2: a) point 1 ; b) point 2 ; c) point 3 ; d) point 4. Rys. 3. Wyniki analizy EDS w punktach wskazanych na Rys. 2: a) punkt 1; b) punkt 2; c) punkt 3; d) punkt 4

\subsection{MixtuRE PROPORTIONS}

Concrete mixes were designed with constant water to binder ratio $w / b=0.50$. In all the mixtures incorporating $\mathrm{FAB}$, the water/binder ratio is based on the total cement materials, i.e. OPC + FAB solids.

The concretes contained $0,5,15$ or $25 \%$ of fly ash replacement related to cement mass $(\mathrm{FAB} / \mathrm{C})$. The part of fly ash in mixture $(40 \%$ for CEM I 42,5$)$ was taken into account as a binder and the remaining part - as a filler, according to the standard EN 206-1:2003 [8]. Cement content in the control concrete was $350 \mathrm{~kg} / \mathrm{m}^{3}$. The air-entrainer agent (AEA) in amount of $0.1 \%$ of the mass of binder (cement and FAB) was used. The aim of introducing the same amount of AEA was to estimate the admixture efficiency in concrete mix containing fly ash of significant content of 
unburned coal. The composition of all concrete mixes is given in Table 2 The same mixing procedure was used for all concretes:

Dry mixing of normal weight aggregate for $3 \mathrm{~min}$.,

Half the amount of water was added,

Cement (and FAB) was added and mixed for 1 min.,

Finally the rest of water with admixture was added and mixed for 3 min.

The workability, density and air-content were measured directly after mixing. The specimens were vibrated in forms and covered by a plastic film. After de-moulding the specimens were stored for 24 hours in water and then in the air at $20 \pm 2^{\circ} \mathrm{C}$ and $65 \pm 5 \%$ relative humidity until testing.

Table 2

Composition of the concrete mixes in $\mathrm{kg} / \mathrm{m}^{3}$, selected properties of fresh mix and compressive strength. Skład mieszanek betonowych $\mathrm{w} \mathrm{kg} / \mathrm{m}^{3}$, wybrane właściwości mieszanek oraz wyniki wytrzymałości betonów na ściskanie

\begin{tabular}{|c|c|c|c|c|c|c|c|c|c|}
\hline \multirow{3}{*}{ Mix } & \multirow{2}{*}{ Cement } & \multirow{2}{*}{ FAB } & \multirow{2}{*}{ Aggregate } & \multirow{2}{*}{ Water } & \multirow{2}{*}{ AEA } & \multirow{2}{*}{ Density } & \multirow{2}{*}{ Porosity } & \multicolumn{2}{|c|}{ Compressive strength } \\
\hline & & & & & & & & 28 days & 90 days \\
\hline & \multicolumn{6}{|c|}{ Content $\left[\mathrm{kg} / \mathrm{m}^{3}\right]$} & [\%] & \multicolumn{2}{|c|}{$[\mathrm{MPa}]$} \\
\hline $\mathrm{FAB} / \mathrm{C}=0.0$ & 350 & 0.0 & 1887 & 175 & 0.35 & 2114 & 11.0 & 46.9 & 49.0 \\
\hline $\mathrm{FAB} / \mathrm{C}=0.05$ & 343 & 17.2 & 1873 & 175 & 0.35 & 2124 & 10.8 & 43.6 & 54.0 \\
\hline $\mathrm{FAB} / \mathrm{C}=0.15$ & 330 & 49.5 & 1847 & 175 & 0.35 & 2294 & 6.8 & 45.9 & 62.1 \\
\hline $\mathrm{FAB} / \mathrm{C}=0.25$ & 318 & 79.5 & 1823 & 175 & 0.35 & 2367 & 2.5 & 50.0 & 63.4 \\
\hline
\end{tabular}

The morphology of concrete with addition of fly ash from co-combustion was investigated by E-SEM analysis. The examples of the interfacial transition zone for concrete containing $25 \%$ of fly ash related to cement mass as well as for control concrete are presented in Fig 4.

In concrete without fly ash C-S-H phase mixed with portlandite can be seen (Fig. $4 c)$. The clearly marked grain orientation of hydration products - parallel to the surface of the aggregate grain, is visible. The $\mathrm{C}-\mathrm{S}-\mathrm{H}$ concentrations, showed in Figs $4 \mathrm{a}$ and $4 \mathrm{e}$, can be credited to C-S-H III according to Diamond.

The spatial forms of hydrated calcium silicates of C-S-H II were observed in concrete containing fly ash from what-combustion (Figs 4b, 4d, 4f). The compact layer of homogeneous $\mathrm{Ca}(\mathrm{OH})_{2}$ is showed in Fig. $4 \mathrm{~d}$.

\subsection{DESCRIPTION OF THE TEST PROCEDURE FOR SCALING}

Freeze/thaw exposure was carried out on one-dimensional, upper horizontal surface of the specimens - cutting surface, while the remaining surfaces were isolated against humidity and heat transfer. Every series was composed of 3 cubes.

After 28 days of curing, a $50 \mathrm{~mm}$ thick specimen was sawn from each cube perpendicular to the top surface, so that the saw cut for the freeze surface was located 
a)

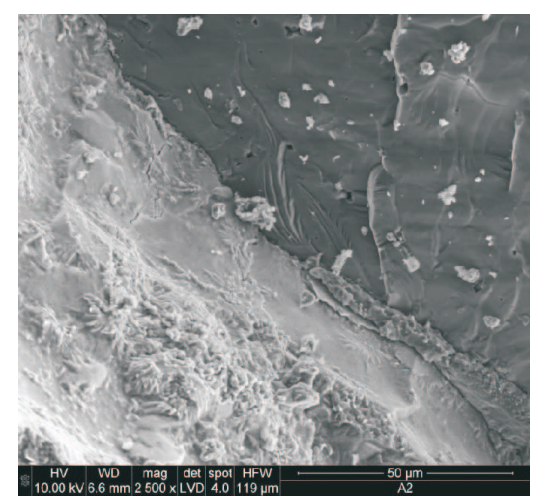

c)

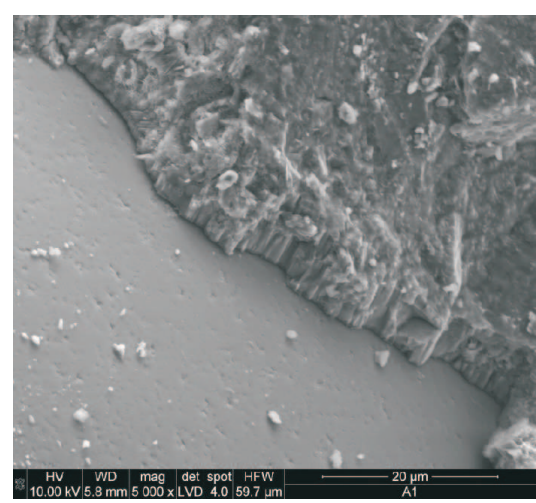

e)

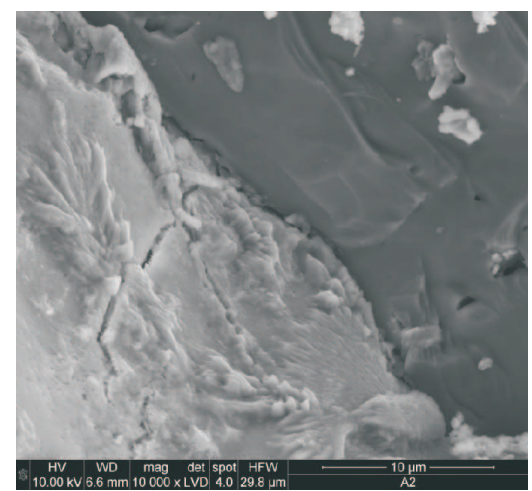

b)

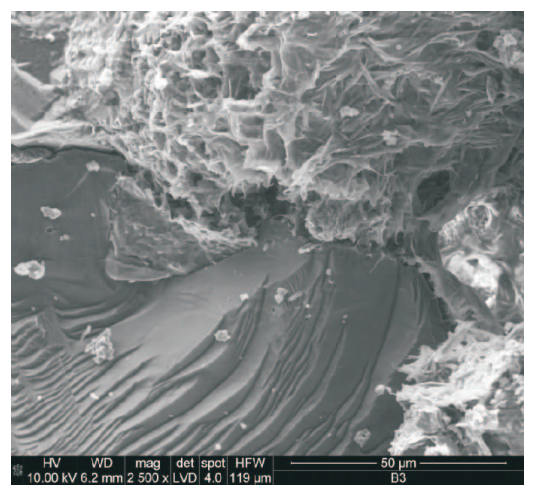

d)

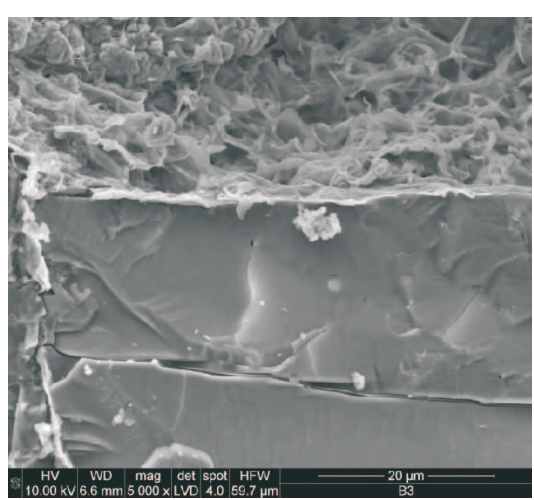

f)

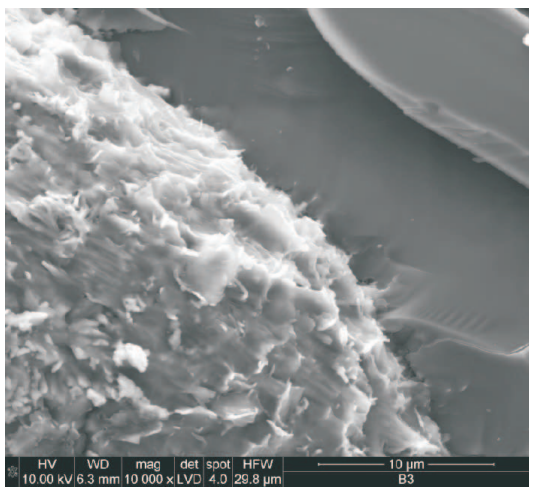

Fig. 4. E-SEM images of concretes tested: $a, c, e)$ without fly ash $(F A B / C=0,0) ; b, d, f)$ with fly ash from co-combustion $(\mathrm{FAB} / \mathrm{C}=0,25)$.

Rys. 4. Zdjęcie z mikroskopu skaningowego wykonane na przełamach badanych betonów: a, c, e) bez dodatku popiołu lotnego $(\mathrm{FAB} / \mathrm{C}=0,0) ; \mathrm{b}, \mathrm{d}, \mathrm{f}$ z popiołem lotnym pochodzącym ze współspalania $(\mathrm{FAB} / \mathrm{C}=0,25)$ 
in the centre of the cube. The rubber sheet was glued to all surfaces of the specimen except the test surface. The edge of the rubber sheet reached $20 \mathrm{~mm}$ above the test surface. Then, all surfaces of the specimen with the exception of the test surface were thermally insulated. The top exposed surface was covered with demineralised water during 72 hours. Directly before the specimens were placed in the freezing chamber, water was replaced by $3 \% \mathrm{NaCl}$ solution. The freezing medium was prevented from evaporating by applying a flat polyethylene sheet. Then the cooling and thawing cycles, each of 24 hours, were applied. The scaled material was collected and weighed after given numbers of freeze/thaw cycles, and the results expressed as mass per unit area have been recorded. The test of the specimens according to the Standard should end after 56 cycles, but the test was carried on up to 112 cycles in order to obtain results after longer exposure. The mean mass of scaled material after 28, 56 and 112 cycles was used for evaluating the scaling resistance, according to the criteria presented in Table 3 .

Table 3

Criteria of the scaling resistance evaluation, [6]. Kryteria oceny odporności betonu na powierzchniowe łuszczenie, [6]

\begin{tabular}{|l|c|}
\hline Scaling resistance & Requirements \\
\hline Very good & $\mathrm{m}_{56}<0.10 \mathrm{~kg} / \mathrm{m}^{2}$ \\
\hline Good & $\begin{array}{c}\mathrm{m}_{56}<0.20 \mathrm{~kg} / \mathrm{m}^{2} \\
\text { or } \mathrm{m}_{56}<0.50 \mathrm{~kg} / \mathrm{m}^{2} \text { and } \mathrm{m}_{56} / \mathrm{m}_{28}<2 \\
\text { (or } \mathrm{m}_{112}<0.50 \mathrm{~kg} / \mathrm{m}^{2} \text { ) }\end{array}$ \\
\hline Admissible & $\begin{array}{c}\mathrm{m}_{56}<1.00 \mathrm{~kg} / \mathrm{m}^{2} \text { and } \mathrm{m}_{56} / \mathrm{m}_{28}<2 \\
\left.\text { (or } \mathrm{m}_{112}<1.00 \mathrm{~kg} / \mathrm{m}^{2}\right)\end{array}$ \\
\hline Inadmissible & $\begin{array}{c}\mathrm{m}_{56}>1.00 \mathrm{~kg} / \mathrm{m}^{2} \text { and } \mathrm{m}_{56} / \mathrm{m}_{28}>2 \\
\left.\text { (or } \mathrm{m}_{112}>1.00 \mathrm{~kg} / \mathrm{m}^{2}\right)\end{array}$ \\
\hline
\end{tabular}

The successive cycles of temperature were measured every hour with the thermometer LB-711 working with 6 surface probe and recorded. Temperatures in the 3\% $\mathrm{NaCl}$ solution layer on the top of the specimen were measured every hour.

\subsection{Description OF THE AIR-VOID ANALYSIS}

Air-content $A$, specific surface $\alpha$, spacing factor $\bar{L}$ and the content of micropores below $0.3 \mathrm{~mm} A_{300}$ in the hardened concrete specimens were measured with the PN-EN 480-11, [12] method on plane sections (computer program ImagePro Plus) after 28 days.

Careful preparation of specimen technique was elaborated in the Institute of Fundamental Technological Research. According to this technique, concrete specimens of planar dimensions $100 \times 100 \mathrm{~mm}$ were polished with $\mathrm{SiC}$ powders of different gradation. After polishing and before acceptance of the preparation, the surface was inspected by using a stereomicroscope to avoid acceptance of the surface with pro- 
cessing defects. The next step was colouring the surface with a blue marker, which was followed by filling the air voids by white, contrast paste. The surplus of the paste was removed and finally the surface was cleaned and protected by oil. At the end, the quality of preparation, especially the accuracy of the air-void filling by the white paste was controlled again under the microscope. If the quality of the surface was poor the whole treatment had to be repeated. The measurements should be carried out only on very carefully prepared specimens, which seemed to be the main point to assure high quality of the results. The image analysis system was composed of image analysis software, software for controlling the scanning table, an automatic scanning table, a stereoscopic microscope, a colour video camera, and a cold light source "swan neck". A special program for automated air void analysis based on the linear traverse method was used, [12]. Each specimen was tested by using 45-traverse lines.

\section{RESULTS AND DISCUSSION}

The data on the density, porosity and compressive strength are given in Table 2 .

Although the same percentage of air-entraining agent was introduced into the concrete mix, the air content in fresh concrete control $(\mathrm{FAB} / \mathrm{C}=0.0)$ was $11 \%$, and in concrete with $\mathrm{FAB} / \mathrm{C}=0.25$ was only just $2.5 \%$. The density of fresh concrete with $\mathrm{FAB} / \mathrm{C}=0.0$ and 0.25 was $2114 \mathrm{~kg} / \mathrm{m}^{3}$ and $2367 \mathrm{~kg} / \mathrm{m}^{3}$, respectively. In order to attain the proper air content in concrete the increased amount of air-entraining agent content in the concrete mix was necessary. Problems with the proper air entrainment were probably related to the high content of unburned coal - loss on ignition in fly ash was equal to $6.9 \%$, because its presence neutralized the air-entraining agent effect.

The form of unburned carbon fly ash appeared to be responsible for the absorption of AEA. A large part of the carbon surface was non-polar compared with the polar surface of the inorganic particles. This provides active absorption sites for the hydrophobic part of the surface, thus the carbon competes with the air/water interface. The interactions between carbon and AEA are discussed in details in [14].

The results of the scaling resistance are given in Fig. 5. The cement replacement by fly ash from co-combustion decreased the scaling resistance of concrete, Fig. 6 . The resistance to scaling (the efficiency of air-entraining agent) was directly connected with fly ash content in concrete mix. Scaling resistance of concrete with $\mathrm{FAB} / \mathrm{C}=0.05$ was very good, comparable with scaling resistance of control concrete $(\mathrm{FAB} / \mathrm{C}=0.0)$, and mass of scaled material did not exceed $0.1 \mathrm{~kg} / \mathrm{m}^{2}$, even after 112 cycles of freezing and thawing. For concrete with $\mathrm{FAB} / \mathrm{C}=0.15$, good scaling resistance was reached, according to the criteria of Table 3, the mean mass of scaling did not exceed $0.2 \mathrm{~kg} / \mathrm{m}^{2}$. Slow increase in mass of scaled material and imperceptible damages of frozen surface were observed.

The addition of $25 \%$ of fly ash related to cement mass caused significant drop in concrete resistance to cyclic freezing and thawing in the presence of de-icing agents. 


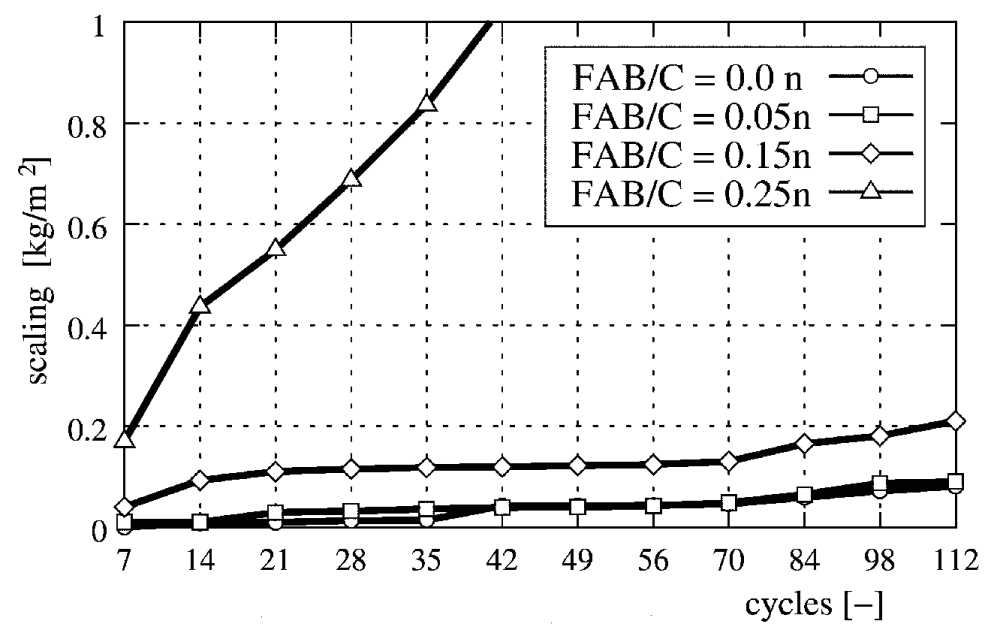

Fig. 5. Results of the scaling resistance tested according to CEN/TS 12390-9:2007, [5]

Rys. 5. Wyniki badania odporności na powierzchniowe łuszczenie wg CEN/TS 12390-9:2007, [5]

After 56 freeze/thaw cycles the mean mass of scaled material was greater than $1 \mathrm{~kg} / \mathrm{m}^{2}$ (Fig. 5).

The results of scaling resistance obtained were directly connected with results of fresh concretes properties. The scaling resistance test was initiated, according to procedure [12], after 28 days of curing, when concretes with fly ash were in phase of significant changes in their microstructure, and this fact should be considered during scaling resistance evaluation.

Table 4 shows the characteristics of the microstructure of air-voids and Fig. 6 distribution of the air content in the classes of their diameters.

Table 4

The microstructure of air-voids.

Wyniki analizy mikrostruktury porów powietrznych

\begin{tabular}{|l|c|c|c|c|}
\hline & Air-content & Specific surface & Spacing factor & $\begin{array}{c}\text { Pore volume } \\
\text { below } 0.3 \mathrm{~mm}\end{array}$ \\
\hline & $A[\%]$ & $\alpha[\mathrm{mm}-1]$ & $\bar{L}[\mathrm{~mm}]$ & $A_{300}[\%]$ \\
\hline $\mathrm{FAB} / \mathrm{C}=0.0$ & 7.64 & 28.57 & 0.10 & 3.20 \\
\hline $\mathrm{FAB} / \mathrm{C}=0.05$ & 6.87 & 29.90 & 0.11 & 3.16 \\
\hline $\mathrm{FAB} / \mathrm{C}=0.15$ & 4.36 & 10.40 & 0.44 & 0.62 \\
\hline $\mathrm{FAB} / \mathrm{C}=0.25$ & 2.32 & 8.26 & 0.74 & 0.21 \\
\hline
\end{tabular}

For all concretes the air-content was decreasing with increasing of the fly ash content. The values of air content, and consequently that of specific surface $\alpha$, spacing factor $\bar{L}$, and content of micropores $A_{300}$ showed very large variations. In the first place, the values of porosity measured in the fresh mix varied from the values of air content measured on concrete plane sections. The best correlation was obtained for concrete 


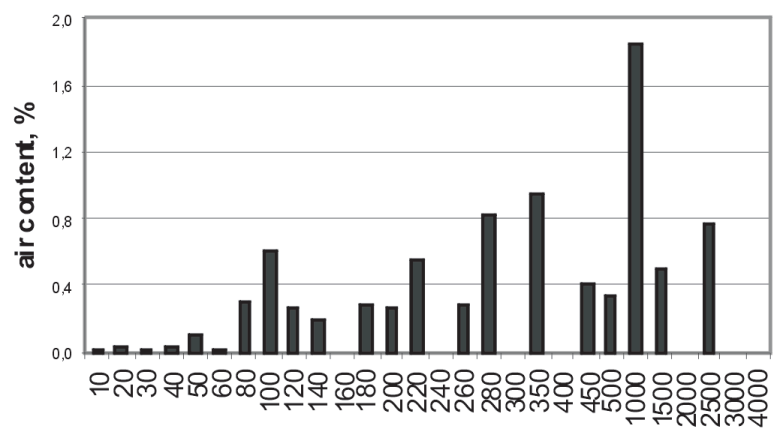

diameter, um

$\mathrm{FAB} / \mathrm{C}=0.0$

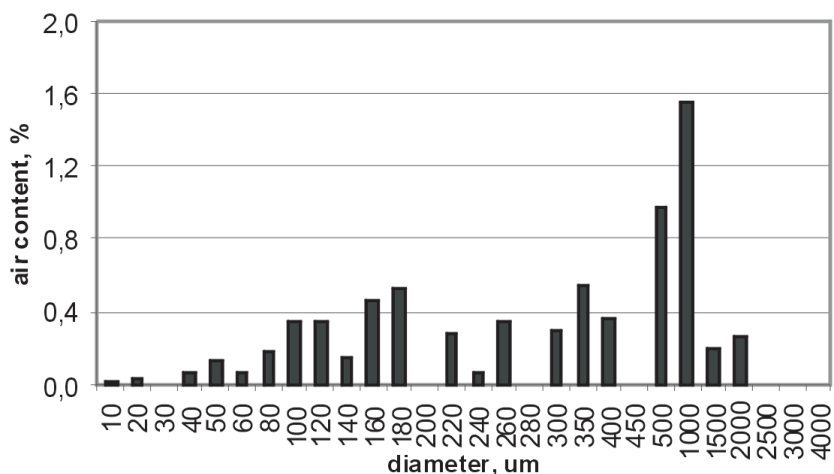

$\mathrm{FAB} / \mathrm{C}=0.05$

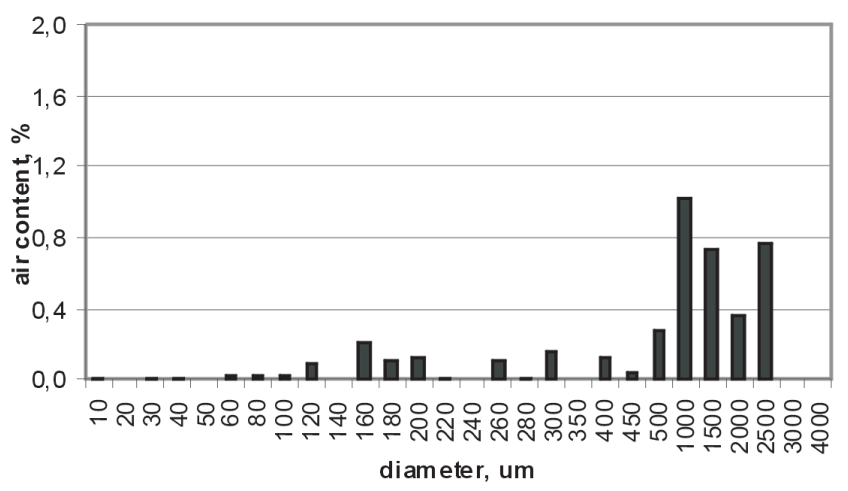

$\mathrm{FAB} / \mathrm{C}=0.15$ 


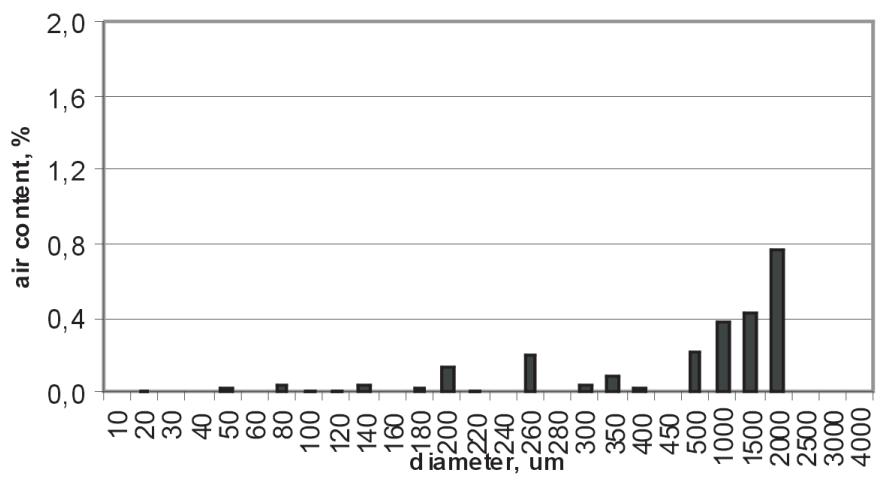

$\mathrm{FAB} / \mathrm{C}=0.25$

Fig. 6. Distribution of the air content in the classes of the concrete air-voids diameters for different content of FAB

Rys. 6. Rozkład zawartości porów powietrznych w zależności od średnicy pora w betonach z różną zawartością FAB

with $15 \%$ of cement replacement by FAB. The total air content of concretes varied from $2.32 \%$ to $7.64 \%$. Concrete without fly ash addition has showed higher porosity than other concretes. Fig. 6 presents distribution of the air content in the classes of the concrete air-voids diameters. It is clearly visible that the content of pore volume below $0.3 \mathrm{~mm}$ is dramatically low in concrete with $25 \%$ of FAB. The content of micropores below $300 \mu \mathrm{m}$ decreased with increasing of fly ash content. The values of spacing factor varied from $0.10 \mathrm{~mm}$ - concrete without fly ash, to $0.74-25 \%$ of fly ash replacement.

In Fig. 7, the influence of $\mathrm{FAB} / \mathrm{C}$ is clearly visible. The influence of FAB on the microstructure of air voids is negative, from the point of view of external and internal frost resistance. More the cement replacement by fly ash from co-combustion of hard coal and wood biomass, less the evenly distributed round/spherical air-voids from air-entrainment.

The analysis of test results of total porosity confirmed the influence of fly ash on (of the) efficiency the air-entraining agent used. The air-entraining process had no effect on increase in (the) total porosity of concrete with $\mathrm{FAB} / \mathrm{C}=0.25$.

\section{Conclusions}

Based on the results and discussion, the following conclusions are proposed:

1. The phase composition, as well as chemical composition, of fly ash from co-combus- tion of hard coal and wood biomass differs from these of a conventional fly ash. The tested fly ash can be considered as a supplementary cementing material, 


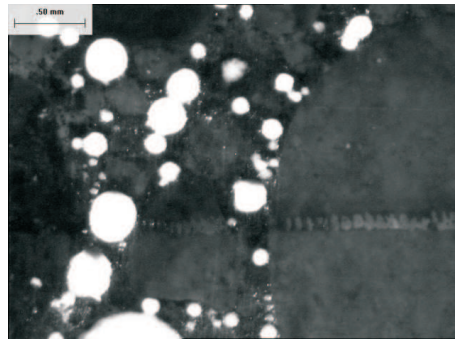

$\mathrm{FAB} / \mathrm{C}=0.0$

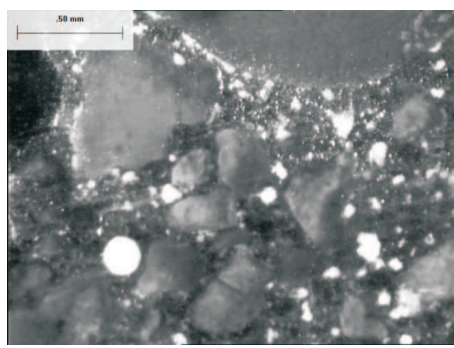

$\mathrm{FAB} / \mathrm{C}=0.15$

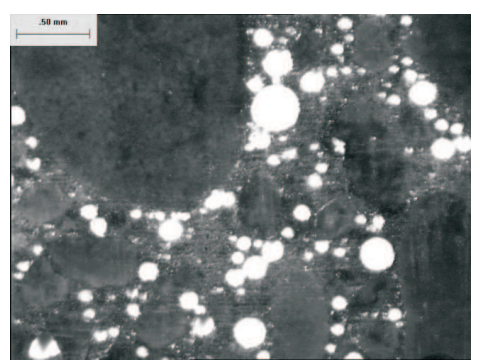

$\mathrm{FAB} / \mathrm{C}=0.05$

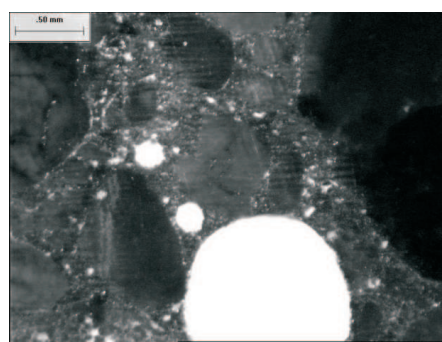

$\mathrm{FAB} / \mathrm{C}=0.25$

Fig. 7. The image of the polished sections of concrete with different content of FAB; air voids - white colour.

Rys. 7. Mikroskopowe fotografie betonów z różną zawartością FAB; na biało zaznaczono pory powietrzne

although the content of biomass in fuel mixture was relatively high. The material points out pozzolanic activity.

2. The rate of strength increase in fly ash concrete is slower and sustains for longer periods. However, the concretes containing fly ash, in considered range of FAB/C values, are capable of developing compressive strength comparable with Portland cement concrete. After 90 days the strength of FAB concretes was higher than in the control concrete (Portland cement concrete) strength.

3. The efficiency of air-entraining agent depends on the fly ash content in a concrete mix. The density and porosity of fresh concrete is strongly affected by fly ash content.

4. The scaling resistance in all tested concretes decreased with the content of FAB, but the changes in scaling resistance for both $5 \%$ and $15 \%$ cement replacement by FAB were not significant.

5. The addition of $25 \%$ of fly ash caused worsening of material's resistance to scaling.

6. Further research is needed in the following directions:

- The compatible performance of air-entraining admixtures and superplasticisers in relation to microstructure of air voids, 
- The influence of $20 \%$ cement replacement by FAB on scaling resistance.

For wider and wider usage of the co-combustion of fossil fuels and biomass, fly ashes arising in this process will be the object of interest of cement and concrete industry. The possibility of the utilization of these ashes as the active concrete addition is determined by their chemical and mineralogical composition. The tested fly ash from co-combustion of coal and biomass can be considered as a supplementary cementing material for manufacturing the ordinary concretes. Considering the variation in properties of the fly ash, its applicability should be verified for every kind of utilization with respect to appropriate conditions.

\section{REFERENCES}

1. V.G. Papadakis, S. Tsimas, Supplementary cementing materials in concrete. Part I: efficiency and design. Cement and Concrete Research, 32, 1525-1532, 2002.

2. F.J.M. LAMERS, J.L.J. Vissers, J.W. VAN DER BERG, Effects of co-combustion of secondary fuels on fly ash quality. Proc. of the $7^{\text {th }}$ CANMET/ACI International Conference on Fly Ash, Silica Fume, Slag and Pozzolans in Concrete, 1, ACI, 433-457, 2001.

3. P. Grammelis, G. Skodras, E. Kakaras, Effect of biomass co-firing with coal on ash properties. Part I: Characterisation and PDS. Fuel, 85, 2310-2315, 2006.

4. N. Koukouzas, J. Hamalainen, D. Papanikolaou, A. Tourunen, T. Jantti, Mineralogical and elemental composition of fly ash from pilot scale fluidised bed combustion of lignite, bituminous coal, wood chips and their blends. Fuel, 86, 2186-2193, 2007.

5. PKN-CEN/TS 12390-9:2007, Testing hardened concrete - Part 9: Freeze-thaw resistance, Scaling.

6. V.S. Ramachandran, J.J. Beaudoin, Handbook of analytical techniques in concrete science and technology. New York: Noyes Publications/William Andrew Publishing, 2001.

7. EN 450-1: 2006 Fly ash for concrete - Definitions, requirements and quality control. European Committee for Standardization, 33.

8. PN-EN 206-1: 2003 Concrete - Part 1: Specification, performance, production, and conformity. European Committee for Standardization, 101.

9. D. Jóźwiak-NiedźwIEDZKa, Scaling resistance and resistivity of concretes containing fluidized bed combustion fly ash, $3^{\text {rd }}$ International Symposium on Non-Traditional Cement\&Concrete, Brno, Czech Republic, 348-355, 2008.

10. D. JóźwIAK-NIEDźwIEdZKa, Scaling resistance of high performance concretes containing a small portion of pre-wetted lightweight fine aggregate, Cement and Concrete Composites, 27, 709-715, 2005.

11. Method for Test of the Frost Resistance of High Performance Concrete, State of Art, HETEK, Report No. 55, 1996.

12. PN-EN 480-11:2008, Admixtures for concrete, mortar and grout: test methods. Part 11, Determination of air void characteristics in hardened concrete.

13. A.M. Brandt et al., Diagnosis of Concrete and High Performance Concrete by Structural Analysis [in Polish], IFTR PAS, Warsaw, 218, 2003.

14. K.H. Pedersen, A.D. Jensen, M.S. Skjoth-Rasmussen, K. Dam-Johansen, A review of the interference of carbon containing fly ash with air entrainment in concrete, Progress in Energy and Combustion Science, 34, 135-154, 2008.

15. A. M. Brand, Cement based composites $-2^{\text {nd }}$ ed: Materialas, mechanical properties and Performance, Taylor \& Francis, UK, 526, 2009. 
16. P. Chindaprasirt, C. Chotithanorm, H.T. Cao, V. Sirivivatnanon, Influence of fly ash fineness on the chloride penetration of concrete, Construction and Building Materials 21, 356-361, 2007.

\title{
5. EXTENDED ABSTRACT
}

Industrial utilization of fly ash from various kinds of fuel plays an important role in the environmentally clean and cost effective power generation. The primary market for fly ash utilization is as a pozzolanic addition in concrete production. The possibility of the utilization of these ashes as an active concrete addition is determined by their chemical and mineralogical composition. The paper concerns the concretes containing fly ash called Fly Ash from Biomass (FAB) from co-combustion of hard coal and wood biomass (wood chips). Characterization of the fly ash was carried on by means of X-ray diffractometry and E-SEM/EDS analysis. The results of laboratory studies undertaken in order to evaluate the influence of FAB on concrete resistance to surface scaling due to cyclic freezing and thawing in the presence of $\mathrm{NaCl}$ solution are presented. The tests were carried out for concretes containing up to $25 \%$ of fly ash related to cement mass. Additionally, the microstructure of air-voids was described.

The tested fly ash can be considered as a supplementary cementing material. The test results pointed out the pozzolanic activity of fly ash. The density and porosity of fresh concrete is strongly affected by fly ash content. The rate of strength increase in fly ash concrete was slower and sustained for longer periods. However, the concretes containing fly ash, in considered range of FAB/C values, were capable of developing the compressive strength comparable with Portland cement concrete strength.

The efficiency of air-entraining agent was influenced by the fly ash content in concrete mix.

The scaling resistance in all tested concretes decreased with the content of FAB, but the changes in scaling resistance, for both $5 \%$ and $15 \%$ cement replacement by FAB, were not significant. The addition of $25 \%$ of fly ash caused worsening of material's resistance to scaling. Considering the variation in properties of the fly ash, its applicability should be verified for every kind of utilization with respect to appropriate conditions.

\section{WPŁYW POPIOŁU LOTNEGO ZE WSPÓŁSPALANIA WĘGLA I BIOMASY NA ODPORNOŚĆ BETONU NA POWIERZCHNIOWE ŁUSZCZENIE}

\author{
Streszczenie
}

Przemysłowe wykorzystanie popiołów pochodzących ze spalania różnych rodzajów paliw ma istotne znaczenie dla ekologicznie czystej i ekonomicznej produkcji energii elektrycznej. Podstawowym sposobem utylizacji popiołów jest ich wykorzystanie w produkcji betonu jako dodatku o właściwościach pucolanowych. Praca dotyczy betonów zawierających popiół lotny (Fly Ash from Biomass, w skrócie FAB) pochodzący ze współspalania węgla kamiennego i biomasy drzewnej (zrębków). Właściwości popiołów określono przy zastosowaniu dyfraktometrii rentgenowskiej i analizy E-SEM/EDS. Przedstawiono wyniki badań laboratoryjnych mające na celu ocenę wpływu FAB na odporność betonu na złuszczenia powierzchniowe pod wpływem cyklicznego zamrażania i rozmrażania w obecności 3\% roztworu NaCl. Przedmiotem badań były betony zawierające do $25 \%$ popiołu lotnego w stosunku do masy cementu. Dodatkowo, 
scharakteryzowano mikrostrukturę porów powietrznych w betonie. Stwierdzono znaczący wpływ popiołu pochodzącego ze współspalania węgla kamiennego i biomasy drzewnej. Odporność na powierzchniowe łuszczenie wszystkich badanych betonów obniżała się wraz ze wzrostem zawartości FAB, jednakże zmiany te, przy zawartości dodatku 5\% i 15\% w stosunku do masy cementu, nie były znaczące. Wprowadzenie $25 \%$ popiołu lotnego spowodowało pogorszenie odporności materiału na powierzchniowe łuszczenie.

Remarks on the paper should be sent to the Editorial Office

Received April 13, 2010

no later than December 30, 2010

revised version

September 15, 2010 